\title{
Ventriculoperitoneal Shunt Infection: A Study about Age as a Risk Factor in Hydrocephalus Pediatrics
}

\author{
Reza Akbar Bastian ${ }^{1 *(D)}$, Handoyo Pramusinto ${ }^{1}$, Endro Basuki $^{1}$, Marianne Marianne $^{2}$ (D) \\ ${ }^{1}$ Department of Surgery, Division of Neurosurgery, Universitas Gadjah Mada, Yogyakarta, Indonesia; ${ }^{2}$ Department of \\ Pharmacology Pharmacy, Faculty of Pharmacy, Universitas Sumatera Utara, Medan, Indonesia
}

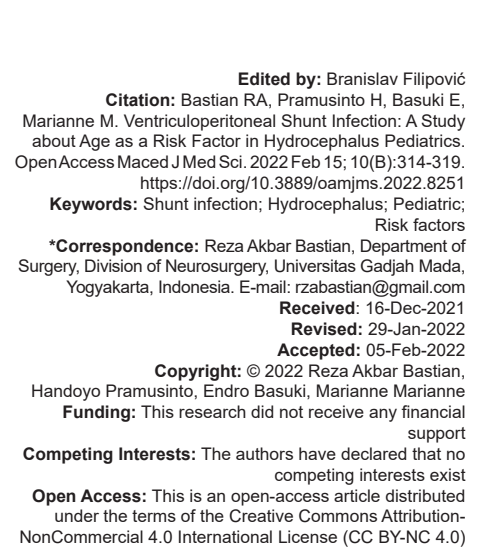

\section{Introduction}

Management for pediatric hydrocephalus patients with ventriculoperitoneal shunt (VP shunt) insertion still has a high failure and complication rate [1], [2]. One of the most dreaded and serious complications following VP shunt is shunt infection [3]. Some studies report a varied incidence of shunt infection; there were $4.4 \%$ in Jakarta, Indonesia, $5.5 \%$ in Denmark, $15.5 \%$ in America, and $17.7 \%$ in Turkey [4], [5], [6], [7]. Pediatric patients tend to be more susceptible to shunt infections than adults, which can be caused by several factors, most commonly in patients <1-year-old, i.e., a perfectly underdeveloped immune system, premature age, exposure to potential pathogens, comorbid diseases, and other physiological factors [7], [8]. Another study, on the other hand, reports the opposite result. Braga et al. reported that patients over the age of 2 years are more vulnerable to infection [9], whereas other research found no correlation between age and shunt infection [10], [11].

Shunt infection has a wide impact on the patients, not only increasing morbidity and mortality but also increasing costs associated with re-admission, procedures related to shunt infection, intravenous administration of antibiotics within a specified time period, and the new shunt system insertion, with an average treatment time of $7-21$ days [12]. Thus, this study aimed to investigate whether there is a relation between the patient's age at the time of VP shunt insertion and shunt infection, especially in neurosurgery patients.

\section{Methods}

This was a retrospective cohort study (historical cohort) in which exposure and disease had occurred before the study's start. The variables of age risk factors during the placement VP shunt were measured through medical records.

\section{Population and sample}

From January 2017 until December 2019, this study included all pediatric patients with 
hydrocephalus who have undergone VP shunt insertion at Dr. Sardjito General Hospital in Yogyakarta. The inclusion criteria were $\leq 18$ years old, diagnosed with hydrocephalus confirmed by clinical and radiological examinations that had undergone VP shunt insertion with conventional shunt system, and had perioperative prophylactic antibiotics. While the exclusion criteria were post-infection hydrocephalus patients with the cerebrospinal fluid (CSF) analysis or bacteria culture result indicating positive growth of bacteria and patients with severe comorbid diseases (congenital heart disease, severe malnutrition, immune system disorders, congenital or systemic disorders that are severe and require further management).

\section{Definition and criteria for infection}

The criteria for shunt infection are at least one of the following criteria [13], [14]:

1. Positively found pathogenic microorganisms in CSF culture or shunt system with appropriate symptoms and signs of central nervous system infection or shunt malfunction; or

2. Surgical wound infection (wound breakdown/ exposed shunt)/signs of infection along the shunt tract; or

3. Abdominal symptoms such as peritoneal infection or pseudocyst (even in the absence of culture-positive specimen).

\section{Age as a risk factor}

Evaluating age as a risk factor for shunt infection by determining and analyzing the age at VP shunt insertion that divided into four groups: $<3$ months, more than 3 months but $<6$ months, more than 6 months but $<12$ months, and more than 12 months.

\section{Analysis and ethics statement}

The following data were collected, processed, and analyzed with univariate and bivariate using SPSS version 25.0 (IBM). This research has obtained ethical clearance approval from the Ethics Commission of the Faculty of Medicine, Public Health and Nursing, Universitas Gadjah Mada, and a permit from Dr. Sardjito General Hospital with Reference Number: KE/FK/0950/ $E C / 2019$ and research permit from the Human Resources and Education Department of the Ministry of Health of the Republic of Indonesia, Directorate General of Health Services, Dr. Sardjito General Hospital number LB.02.01/XI.2.2/22807/2019.

\section{Results}

\section{Patients characteristics}

From January 2017 to December 2019, 98 patients were inserted VP shunt and were eligible as a research subject. All patients underwent surgery by a senior resident accompanied by a pediatric consultant neurosurgeon, utilizing a conventional shunt system; INAShunt semi-lunar flushing valve system with fixed pressure and VP shunt placement were performed at Keen's point. There were 55 males (56.1\%) and 43 females (43.9\%) with a minimum age of 14 days, a maximum of 18 years, and an average age of 5.47 years $( \pm 4.97)$.

\section{Incidence of shunt infection}

Among 98 patients, there were 15 patients $(15.1 \%)$ experienced shunt infection. Nine patients $(60 \%)$ with a diagnosis of an exposed shunt, three patients $(20 \%)$ with ventriculitis, one patient $(6.6 \%)$ with ventriculitis + erythema lesion along the shunt tract, one patient $(6.6 \%)$ with erythema lesion along the shunt tract and one patient $(6.6 \%)$ with ventriculitis + abdominal problems (Figure 1).

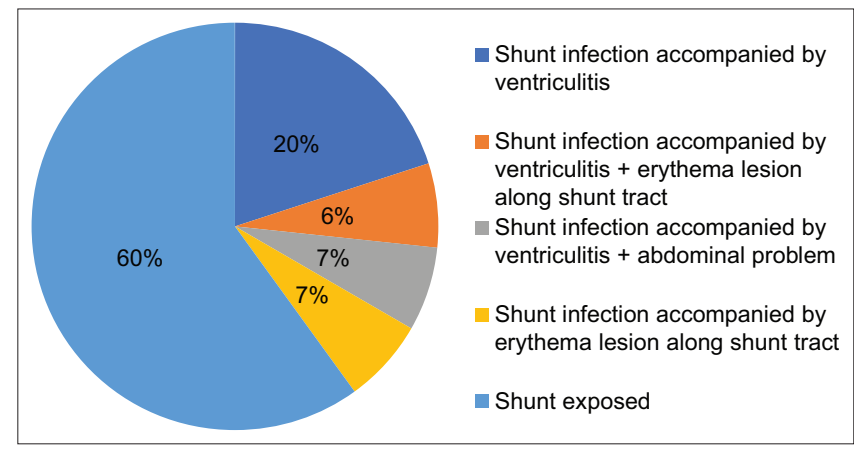

Figure 1: Shunt infection diagnosis

\section{Age as risk factor}

Analyzed by age, the highest shunt infection rate was $>3-6$ months $4 / 13(30.8 \%)$, followed by $\leq 3$ months $6 / 23(26.1 \%)$, >6-12 months $1 / 8(12.5 \%)$, and $>12$ months $4 / 54(7.4 \%)$. Age $>12$ months as reference of the other range. This result found that patients age $>3-6$ months are statistically significantly associated with an increased risk of shunt infection ( $p=0.04$ ) with $\mathrm{RR}=4.15$ which means patients with $>3-6$ months are at risk of infection 4.15 times higher than age $>12$ months, but age $\leq 3$ months and >6-12 months not significant (Table 1).

\section{Microbiology examination}

All patients with shunt infection patients are examined and identified for the pathogen collected 
Table 1: Age as risk factor for shunt infection

\begin{tabular}{|c|c|c|c|c|c|c|c|}
\hline \multirow[t]{3}{*}{ Age } & \multicolumn{4}{|c|}{ Infection } & \multirow[t]{3}{*}{$\mathrm{p}$} & \multirow[t]{3}{*}{ RR } & \multirow[t]{3}{*}{$\mathrm{Cl} 95 \%$} \\
\hline & \multicolumn{2}{|c|}{ Yes } & \multicolumn{2}{|c|}{ Not } & & & \\
\hline & $\mathrm{n}$ & $\%$ & $\mathrm{n}$ & $\%$ & & & \\
\hline$\leq 3$ months & 6 & 26.1 & 17 & 73.9 & 0.057 & 3.52 & $1.09-11.32$ \\
\hline$>3-6$ months & 4 & 30.8 & 9 & 69.2 & 0.040 & 4.15 & $1.19-14.45$ \\
\hline$>6-12$ months & 1 & 12.5 & 7 & 87.5 & 0.511 & 1.69 & $0.22-13.26$ \\
\hline$>12$ months & 4 & 7.4 & 50 & 92.6 & & & \\
\hline
\end{tabular}

from the CSF, pus, or infected tissue/shunt device. The causative pathogens are represented in Table 2. The result shows several patients with monomicrobial and polymicrobial were isolated. Gram-positive bacteria were the predominant pathogen, and the rest were gramnegative bacteria, with the most common pathogen were Staphylococcus aureus (53.3\%), Staphylococcus epidermidis (20\%), and Klebsiella pneumoniae (20\%).

Table 2: Profile of the causative pathogens

\begin{tabular}{llll}
\hline No & Characteristics & Results & \\
\cline { 3 - 4 } & & Amount & Percentage \\
\hline 1 & Staphylococcus aureus & 8 & 53.3 \\
2 & Staphylococcus epidermidis & 3 & 20.0 \\
3 & Klebsiella pneumoniae & 3 & 20.0 \\
4 & Coagulase vegative staphylococcus & 2 & 13.3 \\
5 & Pseudomonas aeruginosa & 2 & 13.3 \\
6 & Staphylococcus haemolyticus & 1 & 6.7 \\
7 & Staphylococcus huminis & 1 & 6.7 \\
8 & Citrobacter amalonaticus & 1 & 6.7 \\
9 & Enterobacter cloacae & 1 & 6.7 \\
\hline
\end{tabular}

\section{Treatment of shunt infection}

Of patients with shunt infection, four patients $(26.6 \%)$ only underwent wound care along with topical and systemic antibiotics, three patients (20\%) underwent shunt externalization and systemic antibiotics, which were then re-inserted after the CSF was sterile, seven patients (46.6\%) underwent complete removal of the shunt and systemic antibiotics followed by re-insertion of the shunt after the CSF was sterile, and one patient $(6.6 \%)$ died before the procedure (Figure 2). The most dominant antibiotic sensitive to cases of shunt infection were tetracycline 5 cases $(7.1 \%)$, vancomycin 5 cases $(7.1 \%)$, and trimethoprim-sulfamethoxazole 5 cases $(7.1 \%)$.

\section{Discussion}

\section{Age as risk factor}

In the age factor for shunt infection, there was a relationship between the age at which the VP shunt was inserted and the incidence of shunt infection, with pediatric patients who had the VP shunt inserted when they were $>3-6$ months old tended to have shunt infection. Previous studies have reported that states that patients aged $<1$ year ( $12 \leq$ months) will increase in the risk of shunt infection [15], [16], a finding that is corroborated by other literature, which indicates that the rate of infection experienced by infants $<6$ months, generally had two to three times greater than adults [6]. Children who are $<1$ year old ( $\leq 12$ months), especially those who are premature or have a low-birth-weight, are at very high risk of shunt infection. It is associated with a not fully developed humoral and cellular immune system, skin barrier protection that tends to be immature, changes in bacterial skin density, comorbidity, and other procedures [8], [15].

Interestingly, not similar to other results, we discovered that patients aged $>3-6$ months $(4 / 13,30.8 \%)$ tend to be more susceptible to infection than $\leq 3$ months $6 / 23(26.1 \%)$. Several theories were tried to explain this discovery. Because the newborn's acquired immune response is still forming, passive antibodies, such as maternal immunoglobulin $\mathrm{G}(\mathrm{lg} \mathrm{G})$ antibodies, play a vital role in the neonate. Transplacental transfer of IgG from the mother to the fetus begins during the first trimester of pregnancy and can reach approximately $50 \%$ of the mother's Ig G level at 30 weeks of gestation and increase to around $50 \%$ at $37-40$ weeks of gestation, frequently exceeding the serum level in mothers delivering in term and healthy pregnancy [17], [18], [19], [20], [21], [22]. One of the IgGs obtained is IgG anti-Sa (S. aureus), which has been shown to improve neonatal resistance against Staphylococcus infection and is also supported by additional breastfeeding immediately after birth [23]. Another theory also mentions the presence of factors that modulate the immune response in neonates [24]. The neonatal serum contains a larger concentration of adenosine, an endogenous purine metabolite with immunomodulatory properties, and a higher basal ratio of interleukin-6 (IL-6)/tumor necrosis factor (TNF) than adults. Additionally, in response to toll-like receptor stimulation, monocytes from neonatal cord blood release a high ratio of IL-6 to TNF. By suppressing the inflammatory response and increasing microglial phagocytosis of $S$. aureus, the toll-like receptor can mediate a congenital immunological response to infection [25], [26], [27].

\section{Microbiology examination}

The most frequently encountered causal pathogen was S. aureus (53.3\%), a gram-positive bacterium. S. aureus and $S$. epidermidis are normal skin flora bacteria that often cause shunt infection through the transmission of the skin, adhere to the implant's surface, and have biofilm-forming bacteria properties [15]. Although several attempts have been made to prevent intraoperative contamination by improving aseptic technique and limiting airborne transmission, the bacteria still dominate the cause of shunt infection. These results are in accordance with a previous report by Sacar et al., who similarly reported high rates of infection with pathogen's patterns that tended to be the same [6]. 


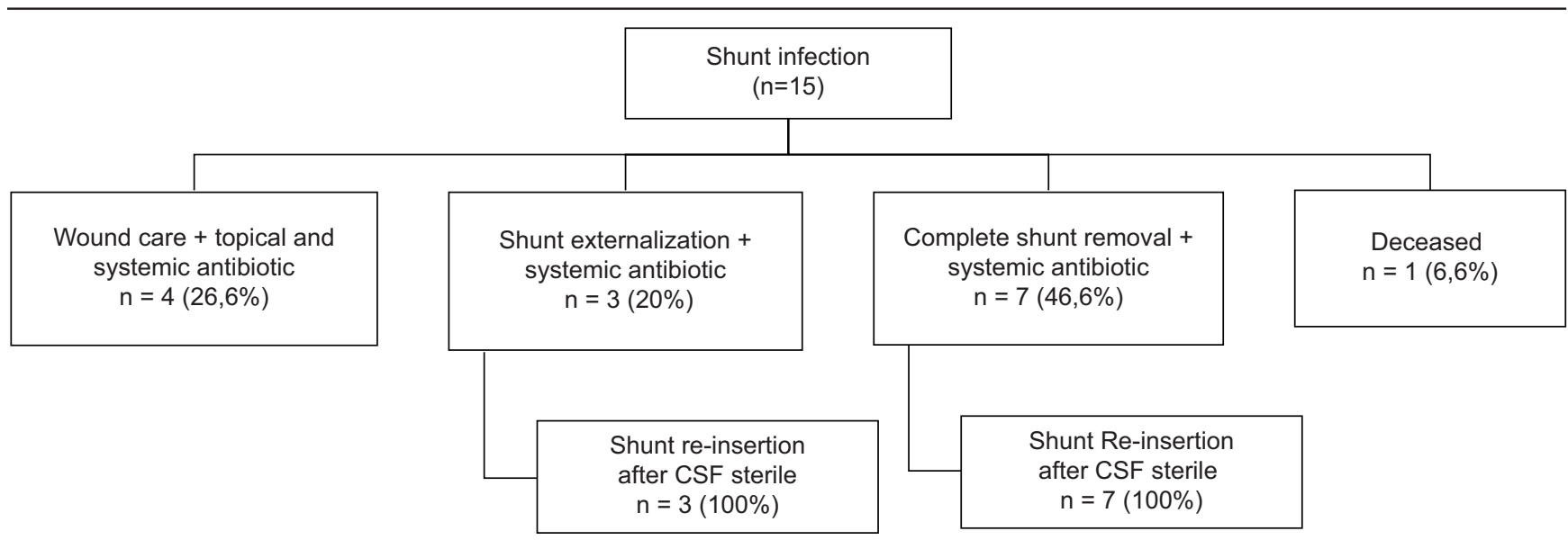

Figure 2: Treatment of shunt infection

This study also found the presence of shunt infections caused by gram-negative bacteria such as K. pneumoniae and Pseudomonas aeruginosa. High levels of gram-negative organisms allow the existence of simultaneous infections in the other part of the body that are responsible for the increased risk of morbidity and mortality. These results are in accordance with a previous report by Sacar et al. where gram-negative bacterial also dominate to be the cause of shunt infection [6]. This study also found some cases with clinical manifestation and symptoms of shunt infection, but with negative results or no pathogens growth, as conveyed by Fux et al., where the diagnosis of cultures and swabs sometimes produces negative results due to the number of microorganisms attached to the surface of the shunt implant and only a small number of cells are found inside the planktonic state [28].

\section{Treatment of shunt infection}

Treatment for shunt infection is determined by the clinical condition of the patients and the doctor's preference. Some patients were only administered with antibiotics (topical and systemic) accompanied by debridement and wound care. Although the study reported by Walters et al. observed a higher mortality rate in shunt infection patients treated only just with antibiotics $(37 \%)$ compared to those treated with antibiotics and surgery (17\%), the cases faced in this study were shunt exposed without signs of systemic infection [29]. This is consistent with a study that determines the procedure for implant-related infections in neurosurgery patients can be determined based on the time of infection, wherein the case of acute infection ( $\leq 6$ weeks) requiring wound debridement while maintaining the implant to remove necrotic tissue and mechanically reducing pathogen load on the implant layer surface, while accompanied by antibiotics [30]. In addition, if the shunt system is still functioning properly, antibiotic management can be combined with wound care/repair flap, and if there is persistent infection following wound care/repair flap, shunt removal can be performed [31]. Some patients performed shunt externalization and complete shunt removal. Both groups were also given systemic antibiotics and re-insertion after the CSF was sterile. A systematic literature review study also provides level II recommendations on managing shunt infection by administering antibiotics along with shunt externalization or complete shunt removal [32].

Evaluation of antibiotic sensitivity found several dominant antibiotics were sensitive to the pathogen's pattern. The antibiotics vancomycin, tetracycline, and trimethoprim-sulfamethoxazole were the most dominantly sensitive. These findings can be considered options in determining prophylactic antibiotics and empirical antibiotics for the treatment of shunt infections. A metaanalysis study conducted that perioperative prophylactic antibiotics for $24-72 \mathrm{~h}$ after surgery can reduce the 50\% risk of shunt infection. However, the function is less effective if the baseline infection is $\leq 5 \%$ [33].

\section{Conclusion}

Throughout 2017-2019, the rate of shunt infection in Dr. Sardjito General Hospital was $15.15 \%$. The patient's age $>3-6$ months at VP Shunt inserted is one of the risk factors that influence the incidence of shunt infection. Gram-positive bacteria became the predominant causative pathogen, with $S$. aureus $(53.3 \%)$ being the most common among the isolates. The management of shunt infection varies greatly depending on clinical conditions and the evaluation of shunt system functions. Evaluation of CSF and shunt system removal are still the primary treatment accompanied by antibiotic administration until sterile CSF is obtained before the VP shunt re-insertion. 


\section{Acknowledgment}

Thanks to Prof. Arifin, B and Prof. Nasution, R for supporting me.

\section{References}

1. $\mathrm{Xu} \mathrm{H}, \mathrm{Hu} F, \mathrm{Hu} H$, Sun $W$, Jiao $W$, Li R, et al. Antibiotic prophylaxis for shunt surgery of children: A systematic review. Childs Nerv Syst. 2016;32(2):253-8. https://doi.org/10.1007/ s00381-015-2937-6

PMid:26499129

2. Hanak BW, Bonow RH, Harris CA, Browd SR. Cerebrospinal fluid shunting complications in children. Pediatr Neurosurg. 2017;52(6):381-400. https://doi.org/10.1159/000452840 PMid:28249297

3. Kulkarni AV, Drake JM, Lamberti-Pasculli M. Cerebrospinal fluid shunt infection: A prospective study of risk factors. J Neurosurg. 2001;94(2):195-201. https://doi.org/10.3171/jns.2001.94.2.0195 PMid:11213954

4. Månsson $\mathrm{P}$, Johansson $\mathrm{S}$, Ziebell $\mathrm{M}$, Juhler $\mathrm{M}$. Forty years of shunt surgery at Rigshospitalet, Denmark: A retrospective study comparing past and present rates and causes of revision and infection. BMJ Open. 2017;7:e013389. https://doi.org/10.1136/ bmjopen-2016-013389

PMid:28093434

5. Fulkerson DH, Vachhrajani $\mathrm{S}$, Bohnstedt $\mathrm{BN}$, Patel NB, Patel AJ, Fox BD, et al. Analysis of the risk of shunt failure or infection related to cerebrospinal fluid cell count, protein level, and glucose levels in low-birth-weight premature infants with posthemorrhagic hydrocephalus. J Neurosurg Pediatr. 2011;7(2):147-51. https://doi.org/10.3171/2010.11.PEDS10244 PMid:21284459

6. Sacar S, Turgut H, Toprak S, Cirak B, Coskun E, Yilmaz O, et al. A retrospective study of central nervous system shunt infections diagnosed in a university hospital during a 4 -year period. BMC Infect Dis. 2006;6:43. https://doi.org/10.1186/1471-2334-6-43 PMid: 16524475

7. Patih AM. Profil Pasien Infeksi Ventrikuloperitoneal Shunt Di Rumah Sakit Cipto Mangunkusumo Periode April 2009-April 2014. Vol. 25. Indonesia: Universitas Indonesia Library; 2014. p. 4-5.

8. Lee JK, Seok JY, Lee JH, Choi EH, Phi JH, Kim SK, et al. Incidence and risk factors of ventriculoperitoneal shunt infections in children: A study of 333 consecutive shunts in 6 years. J Korean Med Sci. 2012;27(12):1563-8. https://doi. org/10.3346/jkms.2012.27.12.1563

PMid:23255859

9. Braga MH, De Carvalho GT, Brandão RA, De Lima FB, Costa BS. Early shunt complications in 46 children with hydrocephalus. Arq Neuropsiquiatr. 2009;67(2 A):273-7. https:// doi.org/10.1590/s0004-282x2009000200019

PMid:19547822

10. Davis SE, Levy ML, McComb JG, Masri-Lavine L. Does age or other factors influence the incidence of ventriculoperitoneal shunt infections? Pediatr Neurosurg. 1999;30(5):253-7. https:// doi.org/10.1159/000028806

PMid:10461072

11. Borgbjerg BM, Gjerris F, Albeck MJ, Børgesen SE. Risk of infection after cerebrospinal fluid shunt: An analysis of 884 firsttime shunts. Acta Neurochir (Wien). 1995;136(1-2):1-7. https:// doi.org/10.1007/BF01411427

PMid:8748819

12. Woo PY, Wong HT, Pu JK, Wong WK, Wong LY, Lee MW, et al Primary ventriculoperitoneal shunting outcomes: A multicentre clinical audit for shunt infection and its risk factors. Hong Kong Med J. 2016;22(5):410-9. https://doi.org/10.12809/hkmj154735 PMid:27562986

13. Sarguna P, Lakshmi V. Ventriculoperitoneal shunt infections Indian J Med Microbiol. 2006;24(1):52-4. https://doi. org/10.4103/0255-0857.19896

PMid: 16505557

14. Kestle JR, Riva-Cambrin J, Wellons JC, Kulkarni AV, Whitehead WE, Walker ML, et al. A standardized protocol to reduce cerebrospinal fluid shunt infection: The hydrocephalus clinical research network quality improvement initiative. J Neurosurg Pediatr. 2011;8(1):22-9. https://doi. org/10.3171/2011.4.PEDS10551

PMid:21721884

15. Gutierrez-Murgas Y, Snowden JN. Ventricular shunt infections: Immunopathogenesis and clinical management. J Neuroimmunol. 2014;276(1-2):1-8. http://dx.doi.org/10.1016/j. jneuroim.2014.08.006 PMid:25156073

16. Lee HJ, Phi JH, Kim SK, Wang KC, Kim SJ. Papilledema in children with hydrocephalus: Incidence and associated factors. J Neurosurg Pediatr. 2017;19(6):627-31. http://dx.doi. org/10.3171/2017.2.PEDS16561 PMid:28387641

17. Pople IK, Bayston R, Hayward RD. Infection of cerebrospinal fluid shunts in infants: A study of etiological factors. J Neurosurg. 1992;77(1):29-36. http://dx.doi.org/10.3171/jns.1992.77.1.0029 PMid:1607969

18. Kloos WE, Musselwhite MS. Distribution and persistence of Staphylococcus and Micrococcus species and other aerobic bacteria on human skin. Appl Microbiol. 1975;30(3):381-95. PMid:810086

19. Orsi GB, d'Ettorre G, Panero A, Chiarini F, Vullo V, Venditti M. Hospital-acquired infection surveillance in a neonatal intensive care unit. Am J Infect Control. 2009;37(3):201-3. https://doi. org/10.1016/j.ajic.2008.05.009

PMid: 19059676

20. Lim WH, Lien R, Huang YC, Chiang MC, Fu RH, Chu SM, et al. Prevalence and pathogen distribution of neonatal sepsis among very-low-birth-weight infants. Pediatr Neonatol. 2012;53(4):228-34. http://dx.doi.org/10.1016/j.pedneo.2012.06.003

PMid:22964280

21. Wang $X$, Mallard C, Levy $O$. Potential role of coagulasenegative Staphylococcus infection in preterm brain injury. Adv Neuroimmune Biol. 2012;3:41-8.

22. Healy CM, Hulten KG, Palazzi DL, Campbell JR, Baker CJ. Emergence of new strains of methicillin-resistant Staphylococcus aureus in a neonatal intensive care unit. Clin Infect Dis. 2004;39(10):1460-6. https://doi.org/10.1086/425321 PMid:15546082

23. Nadaf MI, Lima L, Stranieri I, Takano OA, Carneiro-Sampaio M, Palmeira P. Passive acquisition of anti-Staphylococcus aureus antibodies by newborns via transplacental transfer and breastfeeding, regardless of maternal colonization. Clinics. 2016;71(12):687-94.

24. Belderbos ME, Levy O, Meyaard L, Bont L. Plasma-mediated immune suppression: A neonatal perspective. Pediatr Allergy Immunol. 2013;24(2):102-13. https://doi.org/10.1111/pai.12023 
PMid:23173652

25. Levy O, Coughlin M, Cronstein BN, Roy RM, Desai A, Wessels MR. The adenosine system selectively inhibits TLR-mediated TNF- $\alpha$ production in the human newborn. J Immunol. 2006;177(3):1956-66. https://doi.org/10.4049/ jimmunol.177.3.1956

PMid:16849509

26. Angelone DF, Wessels MR, Coughlin M, Suter EE, Valentini $P$, Kalish LA, et al. Innate immunity of the human newborn is polarized toward a high ratio of IL-6/TNF- $\alpha$ production in vitro and in vivo. Pediatr Res. 2006;60(2):205-9. https://doi. org/10.1203/01.pdr.0000228319.10481.ea

PMid:16864705

27. Kochan T, Singla A, Tosi J, Kumar A. Toll-like receptor 2 ligand pretreatment attenuates retinal microglial inflammatory response but enhances phagocytic activity toward Staphylococcus aureus. Infect Immun. 2012;80(6):2076-88. https://doi.org/10.1128/ IAI.00149-12 PMid:22431652

28. Fux C, Quigley M, Worel A, Post C, Zimmerli S, Ehrlich G, et al. Biofilm-related infections of cerebrospinal fluid shunts. Clin Microbiol Infect. 2006;12(4):331-7. https://doi. org/10.1111/j.1469-0691.2006.01361.x PMid:16524409

29. Walters BC, Hoffman HJ, Hendrick EB, Humphreys RP.
Cerebrospinal fluid shunt infection. Influences on initial management and subsequent outcome. J Neurosurg. 1984;60(5):1014-21. https://doi.org/10.3171/jns.1984.60.5.1014 PMid:6716136

30. Conen A, Raabe A, Schaller K, Fux CA, Vajkoczy P, Trampuz A. Management of neurosurgical implant-associated infections. Swiss Med Wkly. 2020;150(1):w20208. https://doi.org/10.4414/ smw.2020.20208

PMid:32329803

31. Akdag O. Management of exposed ventriculoperitoneal shunt on the scalp in pediatric patients. Child's Nerv Syst. 2018;34(6):122933. https://doi.org/10.1007/s00381-017-3702-9

PMid:29396717

32. Tamber MS, Klimo P, Mazzola CA, Flannery AM. Pediatric hydrocephalus: Systematic literature review and evidencebased guidelines. Part 8: Management of cerebrospinal fluid shunt infection. J Neurosurg Pediatr. 2014;14(1):60-71. https:// doi.org/10.3171/2014.7.PEDS14328 PMid:25988784

33. Ratilal B, Costa J, Sampaio C. Antibiotic prophylaxis for surgical introduction of intracranial ventricular shunts: A systematic review. J Neurosurg Pediatr. 2008;1(1):48-56. https://doi. org/10.3171/PED-08/01/048

PMid:18352803 